\title{
PENGARUH SOFTWARE MATLAB TERHADAP KEMAMPUAN MENYELESAIKAN MASALAH PROGRAM LINIER
}

\author{
Erna Puji Astutik 1)* dan Sri Rahmawati Fitriatien ${ }^{2)}$ \\ ${ }^{1,2)}$ Program Studi Pendidikan Matematika, Fakultas Keguruan dan Ilmu Pendidikan, \\ Universitas PGRI Adi Buana Surabaya \\ Jalan Ngagel Dadi III-B/37 Surabaya, 60234 \\ *erna_pa@unipasby.ac.id
}

\begin{abstract}
Abstrak
Penelitian ini menggunakan pendekatan kuantitatif dengan desain Quasi Experimen menggunakan dua kelas sebagai sampel penelitian. Dua kelas yang digunakan adalah mahasiswa program studi pendidikan matematika Universitas PGRI Adi Buana Surabaya kelas 2016A sebagai kelompok kelas eksperimen dan 2016B sebagai kelompok kelas kontrol. Tujuan dari penelitian iniuntuk mengetahui pengaruh penggunaan software MATLAB terhadap kemampuan mahasiswa program studi pendidikan matematika Universitas PGRI Adi Buana Surabaya dalam menyelesaikan masalah program linier. Untuk menguji keberhasilan mahasiswa dalam menggunakan software MATLAB guna menyelesaikan masalah program linear sesuai dengan masing-masing kemampuan mahasiswa, peneliti menggunakan angket respon mahasiswa yang kemudian dilakukan validasi dan kevalidan hasil melalui uji Mann Whitney. Hasil penelitian ini menunjukkan bahwa adanya pengaruh dari penerapan software MATLAB terhadap kemampuan mahasiswa di kelas 2016A dan $2016 B$ program studi pendidikan matematika Universitas PGRI Adi Buana Surabaya dalam menyelesaikan masalah program linier. Hal ini terlihat dari hasil uji Mann Whitney untuk nilai U sebesar 308.500 dengan nilai sig. (p-value) sebesar $0.000<0.05$. Selain itu, melalui penerapan software MATLAB dalam pembelajaran program linier di program studi pendidikan matematika Universitas PGRI Adi Buana Surabaya memperoleh respon positif yang terlihat dari respon mahasiswa merasa senang dengan adanya penerapan software MATLAB, mahasiswa memahami dan dapat menggunakan software MATLAB untuk menyelesaikan masalah program linier, serta mahasiswa tidak mengalami kesulitan dalam menyelesaikan masalah program linier menggunakan software MATLAB.
\end{abstract}

Kata Kunci: pengaruh, software MATLAB, penyelesaian masalah, program linier.

\section{PENDAHULUAN}

Program linier merupakan salah satu program untuk menyelesaikan permasalahan yang dibagi menjadi dua bagian yaitu fungsi kendala dan fungsi objektif, dimana batasan fungsi kendala dalam bentuk 
pertidaksamaan. Fungsi kendala pada program linier adalah fungsi yang memberi batasan-batasan yang harus dipenuhi untuk permasalahan, sedangkan untuk fungsi objektif merupakan fungsi yang dioptimumkan nilainya yaitu dimaksimumkan atau diminimumkan. Untuk menentukan fungsi kendala dan fungsi objektif pada program linier, terlebih dahulu dilakukan proses interpretasi dalam menterjemahkan atau merumuskan kendalakendala (batasan-batasan) yang ada ke dalam bentuk model matematika sehingga dapat diselesaikan secara matematis.

Perkembangan masalah program linier memunculkan metode-metode baru untuk menyelesaikannya. Awalnya muncul metode simpleks untuk menyelesaian masalah program linier dimana melalui prosedur aljabar iteratif (yang dilakukan secara berulang) yang dimulai dari suatu penyelesaian layak basis awal ke penyelesaian layak basis lainnya sampai diperoleh penyelesaian yang optimal. Setiap langkah pada metode simpleks ini menghasilkan suatu nilai dari fungsi tujuan yang selalu lebih besar (lebih kecil) atau sama dari langkah-langkah sebelumnya (Indriani, Suyitno, Mashuri, 2013:98-106).

Metode simpleks juga tidak sepenuhnya dapat menyelesaikan permasalahan linier, karena jika dihadapkan pada kendala yang banyak dan kompleks, metode simpleks kurang efisien karena banyaknya proses iterasi yang dihasilkan sehingga menimbulkan perhitungan waktu yang lama (Zulfikarijah, 2004). Oleh karena itu, peneliti selaku dosen di program studi pendidikan matematika Universitas PGRI Adi Buana Surabaya memanfaatkan kemajuan teknologi yang berkembang saat ini yaitu dengan mengintegrasikan komputer dan atau smartphone untuk proses pembelajaran. Teknologi yang digunakan pada proses pembelajaran ini adalah software MATLAB yang dapat digunakan baik melalui komputer di Laboratorium Komputasi Matematika Universitas PGRI Adi Buana Surabaya maupun software MATLAB yang dapat diakses melalui smartphone.

Program linier merupakan salah satu materi yang terdapat di dalam mata kuliah operasional riset, dimana peneliti mengampu mata kuliah tersebut. Peneliti menggunakan strategi pembelajaran yang banyak melibatkan mahasiswa aktif dalam belajar, seperti mahasiswa dapat mengamati, mengaplikasikan, maupun menjawab pertanyaan-pertanyaan dan berdiskusi baik di kelas maupun di Laboratorium Komputasi Matematika Universitas PGRI Adi Buana Surabaya. Peneliti memilih menggunakan software MATLAB yang telah terintegrasikan dengan komputer maupun smartphone guna menyelesaikan program linier apabila terdapat fungsi kendala yang banyak dan kompleks.

\begin{tabular}{|c|c|}
\hline oftware & MATLAB \\
\hline kan & $\begin{array}{l}\text { Mathworks } \\
\text { program }\end{array}$ \\
\hline
\end{tabular}
diperutukkan guna melakukan analisis dan komputasi numerik menggunakan bahasa pemrograman matematika lanjutan yang dibentuk atas dasar penggunaan sifat dan bentuk matkris (Sobiruddin, 2015: 24-32). Dengan memanfaatkan software MATLAB pada materi program linier diharapkan mahasiswa program studi pendidikan matematika Universitas PGRI Adi Buana Surabaya dapat memahami dan menyelesaikan masalah program linier yang bersifat lebi kompleks.

Adapun fitur yang dimiliki oleh software MATLAB antara lain adalah (1) perhitungan matematika, (2) komputasi numerik, (3) simulasi dan pemodelan, (4) visualisasi dan analisis data, (5) pembuatan 
grafik untuk keperluan sains dan teknik, dan

(6) pembembangan aplikasi. Berikut tampilan desktop untuk software MATLAB versi 6.5 sekaligus dengan keterangan gambar.

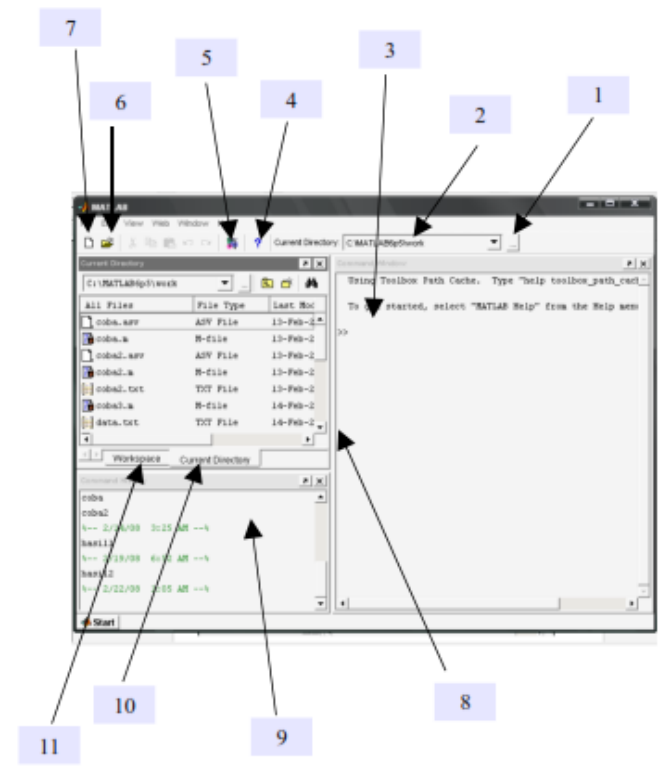

Gambar 1. Tampilan Desktop MATLAB versi 6.5

Keterangan Gambar 1:

1. Tool untuk browse direktori aktif

2. Tool yang menampilkan direktori aktif

3. Command Window untuk memasukkan perintah MATLAB

4. Tool bantuan pada MATLAB

5. Tool yang digunakan untuk menuju Simulink Library Browser

6. Tool untuk membuka file yang ada di direktori aktif

7. Tool untuk membuat file baru dengan format M-File

8. Tool untuk mengatur ukuran jendela

9. Command history untuk melihat perintah apa saja yang pernah kita jalankan melalui command window

10. Tool untuk mendisplay isi file apa saja yang terdapat di direktori aktif

11. Tool untuk mendisplay nama variabel, ukuran, bytes, dan classnya
Penelitian yang melibatkan teknologi dalam penyelesaian masalah progam linier pernah dilakukan oleh Hastri Rosiyanti dengan menggunakan software LINDO yang dikombinasikan pada metode pembelajaran penemuan terbimbing dengan menggunakan jenis penelitian tindakan kelas. Pada penelitian ini, software LINDO yang digunakan oleh mahasiswa pendidikan matematika angkatan 2013 FIP Universitas Muhammadiyah Jakarta secara umum terjadi peningkatan motivasi belajar untuk mata kuliah program linier dengan metode pembelajaran penemuan terbimbing berbantuan software LINDO mencapai $75,11 \%$ sehingga dapat dikatakan bahwa software LINDO menjadi alternatif software untuk digunakan dalam pembelajaran khususnya pada mata kuliah program linier di Universitas Muhammadiyah Jakarta (Rosiyanti, 2016: 19-27).

Penggunaan teknologi juga digunakan oleh Dian Novita melalui media interaktif untuk mengamati pengaruh penggunaan multimedia interaktif terhadap kemampuan pemahaman konsep matematis siswa. Pada penelitian ini menunjukkan bahwa penggunaan multimedia interaktif memiliki pengaruh terhadap kemampuan pemahaman konsep matematis siswa dengan perolehan rata-rata kelas eksperimen lebih tinggi jika dibandingan dengan kelas kontrol (Novita, 2016:8-18).

\section{METODE PENELITIAN}

Penelitian ini menggunakan quasi experiment dengan pengambilan sampel secara random (Sugiyono, 2013). Penelitian ini dilaksanakan pada mahasiswa Angkatan 2016 (Kelas A dan B) Program Studi Pendidikan Matematika Semester Genap Tahun Ajaran 2017/2018. Pada penelitian ini, kelompok mahasiswa kelas 2016A 
sebagai kelompok kelas eksperimen yang diajarkan menggunakan software MATLAB, sedangkan 2016B sebagai kelompok kelas kontrol yang diajarkan tanpa menggunakan software MATLAB. Rancangan penelitian ini menggunakan pendekatan kuantitatif yang analisis secara umum dilakukan analisis statistik dengan bentuk desain Quasi Experimental Design dengan Nonequivalent Control Group Design. Desain jenis ini hampir sama dengan pretest-posttest control group design, hanya pada desain ini kelompok eksperimen dan kelompok kontrol tidak dipilih secara random (Sugiyono, 2017).

Pengumpulan data pada penelitian ini dilakukan melalui proses pengamatan terhadap pembelajaran dengan menggunakan software MATLAB untuk materi program linier, selanjutnya diberikan tes untuk mengukur kemampuan mahasiswa dalam menyelesaikan masalah program linier. Peneliti melakukan penyebaran angket respon mahasiswa guna mengetahui respon mahasiswa terhadap pembelajaran yang menggunakan software MATLAB untuk materi program linier.

Pada tahapan analisis data, guna mengetahui ada tidaknya pengaruh software MATLAB terhadap kemampuan menyelesaikan masalah pada materi program linier peneliti menggunakan uji Mann Whitney untuk menguji perbedaan antara kemampuan mahasiswa di kelas eksperimen dan kelas kontrol. Sedangkan untuk mengetahui respon mahasiswa setelah penerapan software MATLAB, peneliti menggunakan hasil angket yang kemudian dideskripsikan (Astutik, Fitriatien. 2016).

\section{HASIL DAN PEMBAHASAN}

Untuk melihat ada tidaknya pengaruh penerapan software MATLAB terhadap kemampuan menyelesaiakan masalah program linier mahasiswa akan digunakan uji beda antara nilai kelas 2016A yang diajarkan tanpa software MATLAB dengan kelas 2016B yang diajarkan dengan memanfaatkan software MATLAB. Nilai tersebut kemudian dianalisis dengan menggunakan SPSS. Kemampuan mahasiswa dalam menyelesaikan permasalahan program linier disajikan pada gambar berikut ini.

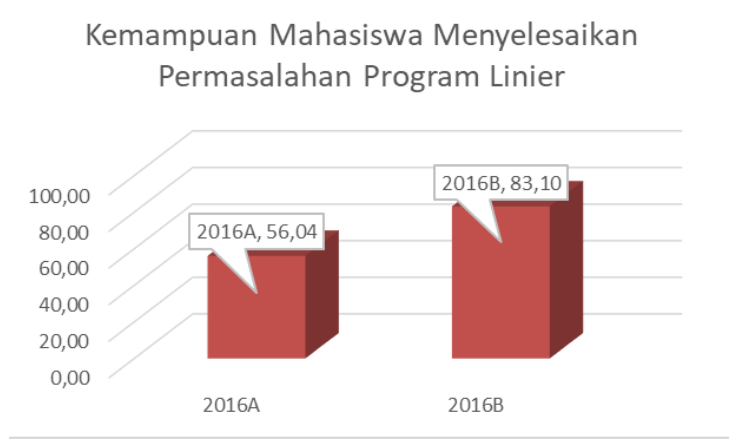

Gambar 2. Kemampuan Mahasiswa Menyelesaikan Masalah Program Linier

Berdasarkan Gambar 2 di atas, diperoleh perbedaan rata-rata kemampuan mahasiswa dalam menyelesaikan masalah program linier dimana nilai kelas 2016B yang diajarkan dengan softwareMATLAB sebesar 83,10 lebih tinggi daripada kelas 2016A yang diajarkan tanpa software MATLAB yaitu sebesar 56,05. Perbedaan data tersebut selanjutnya akan dianalisis signifikan atau tidak dengan menggunakan SPSS.

Sebelum uji siginifikan terlebih dahulu dilakukan uji normalitas data sebagai berikut. 
Erna Puji Astutik dan Sri Rahmawati Fitriatien : Pengaruh Software Matlab Terhadap Kemampuan Menyelesaikan Masalah Program Linier

FIBONACCI : Jurnal Pendidikan Matematika dan Matematika. Vol. 5 (2), pp: 175-182.

Tabel 1. Tabel Uji Normalitas

\section{Tests of Normality}

\begin{tabular}{cc}
$\begin{array}{c}\text { Kolmogorov- } \\
\text { Smirnov }^{\mathrm{a}}\end{array}$ & Shapiro-Wilk \\
\hline
\end{tabular}

KELAS Statistic df Sig. Statistic df Sig.

\begin{tabular}{|c|c|c|c|}
\hline \multirow{2}{*}{$\begin{array}{l}\text { NILA } \\
\text { I }\end{array}$} & $2016 \mathrm{~A}$ & 169. & 025.945. 48. \\
\hline & & 48.000 & 66848 \\
\hline
\end{tabular}

a. Lilliefors Significance Correction

Berdasarkan tabel uji normalitas di atas terdapat nilai sig. ( $p$-value $)<0.05$ yang berarti data tidak berdistribusi normal yaitu pada kelas 2016B. Selanjutnya dilakukan uji homogenitas yang hasilnya disajikan sebagai berikut.

Tabel 2. Tabel Uji Homogenitas

Test of Homogeneity of Variance

\begin{tabular}{|c|c|c|c|c|c|}
\hline & & $\begin{array}{l}\text { Levene } \\
\text { Statistic }\end{array}$ & & df2 & Sig. \\
\hline \multirow[t]{4}{*}{ NILAI } & Based on Mean & .385 & 1 & 94 & .537 \\
\hline & Based on Median & .637 & 1 & 94 & .427 \\
\hline & $\begin{array}{l}\text { Based on Median } \\
\text { and with adjusted } \\
\text { df }\end{array}$ & .637 & 1 & 79.412 & .427 \\
\hline & $\begin{array}{l}\text { Based on } \\
\text { trimmed mean }\end{array}$ & .220 & 1 & 94 & .640 \\
\hline
\end{tabular}

Tabel 2 di atas menunjukkan hasil uji homogenitas dengan menggunakan Levene's test. Uji tersebut dilakukan untuk menguji homogentitas pada data yang tidak berdistribusi normal. Nilai uji Levene's test ditunjukkan pada baris based on mean yaitu sig. (p-value) 0.385>0.05 yang berarti varians kedua kelas sama atau homogen.

Selanjutnya, untuk mengetahui nilai signifikansi ada tidaknya perbedaan dilakukan rata-rata kemampuan menyelesaikan masalah program linier pada kelas 2016A dan 2016B dilakukan dengan uji Mann Whitney. Uji ini dilakukan karena data tidak berdistribusi normal.

Tabel 3. Tabel Uji Mann Whitney

Ranks

\begin{tabular}{ccccc}
\hline & KELAS & $\mathrm{N}$ & $\begin{array}{c}\text { Mean } \\
\text { Rank }\end{array}$ & $\begin{array}{c}\text { Sum of } \\
\text { Ranks }\end{array}$ \\
\hline NILAI & $2016 \mathrm{~A}$ & 48 & 30.93 & 1484.50 \\
\cline { 2 - 5 } & 2016B & 48 & 66.07 & 3171.50 \\
\cline { 2 - 4 } & Total & 96 & & \\
\end{tabular}

Test Statistics $^{\mathbf{a}}$

\begin{tabular}{lr}
\hline & \multicolumn{2}{c}{ NILAI } \\
\hline Mann-Whitney U & 308.500 \\
\hline Wilcoxon W & $1.484 \mathrm{E} 3$ \\
\hline $\mathrm{Z}$ & -6.310 \\
\hline Asymp. Sig. (2-tailed) & .000 \\
\hline
\end{tabular}

a. Grouping Variable: KELAS

Berdasarkan tabel di atas diperoleh nilai $U$ sebesar 308.500 dengan nilai sig. ( $p$ value) sebesar $0,000<0,05$ yang artinya terdapat perbedaan rata-rata kemampuan menyelesaikan masalah program linier yang bermakna/signifikan antara kelas 2016A dan 2016B. Dikarenakan kedua kelas homogen dan terdapat perbedaan yang signifikan dalam kemampuan masalah program linier maka dapat diasumsikan bahwa yang membuat perbedaan tersebut adalah metode yang digunakan yaitu adanya penerapan software MATLAB. Sehingga dapat disimpulkan bahwa terdapat pengaruh penerapan software MATLAB terhadap kemampuan menyelesaikan masalah program linier mahasiswa program studi 
Pendidikan Matematika Universitas PGRI Adi Buana Surabaya.

Selanjutnya, respon mahasiswa program studi pendidikan matematika Universitas PGRI Adi Buana Surabaya setelah penerapan software MATLAB pada materi program linier dapat dilihat dari angket respon mahasiswa. Angket respon mahasiswa dibagikan setelah pembelajaran program linier dengan menerapkan software MATLAB berakhir pada pertemuan kedua di kelas 2016B. Angket berisi tentang tanggapan mahasiswa terhadap pembelajaran dengan software MATLAB yang telah dilakukan. Dari hasil angket diperoleh data sebagai berikut.

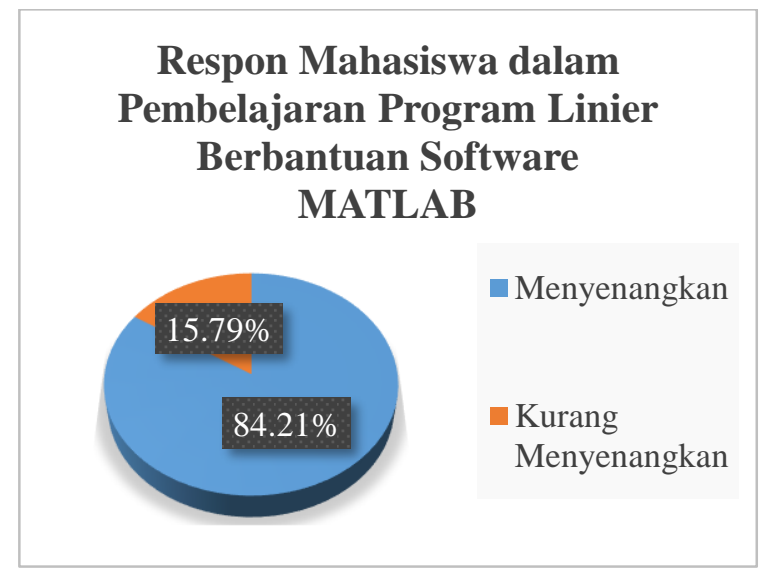

Gambar 3. Respon Mahasiswa dalam Pembelajaran Program Linier Berbantuan Software MATLAB

\section{Respon Kemampuan}

Pemahaman Mahasiswa dalam Pembelajaran Program Linier Berbantuan Software MATLAB

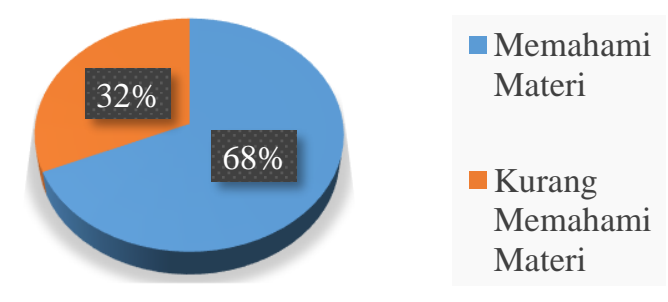 \\ Gambar Pemahaman \\ 4. Respon Kemampuan Mahasiswa dalam}

Pembelajaran Program Linier Berbantuan Software MATLAB

\section{Respon Kemampuan Mahasiswa dalam Menyelesaikan Program Linier Berbantuan Software MATLAB}

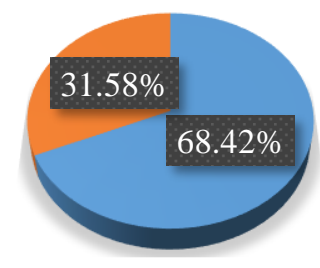

$$
\begin{aligned}
& \text { Mampu } \\
& \text { Menyelesaikan } \\
& \text { Masalah PL } \\
& \text { Tidak Mampu } \\
& \text { Menyelesaikan } \\
& \text { Masalah PL }
\end{aligned}
$$

\section{Gambar 5. Respon Kemampuan Pemahaman Mahasiswa dalam Menyelesaikan Program Linier Berbantuan Software MATLAB}

\section{Respon Kesulitan Mahasiswa dalam Pembelajaran Program Linier Berbantuan Software MATLAB}

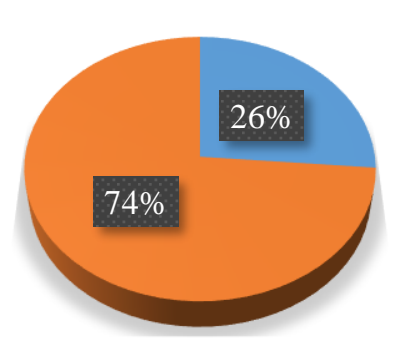

$$
\begin{aligned}
& \text { Kesulitan dalam } \\
& \text { Menyelesaikan PL } \\
& \\
& \text { Tidak Mengalami } \\
& \text { Kesulitan dalam } \\
& \text { Menyelesaikan PL }
\end{aligned}
$$

Gambar 6. Respon Kesulitan Mahasiswa dalam Pembelajaran Program Linier Berbantuan Software MATLAB

Berdasarkan data angket di atas dapat dijelaskan bahwa rata-rata mahasiswa memberikan respon positif terhadap pembelajaran dengan software MATLAB pada materi program linier. Sebanyak 84,21\% mahasiswa merasa senang dengan adanya penerapan software MATLAB pada materi program linier, 68,42\% mahasiswa memahami dan dapat menggunakan software MATLAB untuk menyelesaikan masalah program linear, serta $73,68 \%$ mahasiswa tidak mengalami kesulitan dalam 
menyelesaikan masalah program linear dengan menggunakan software MATLAB.

Berdasarkan angket juga diperoleh alasan dari jawaban mahasiswa bahwa pembelajaran program linear dengan penerapan software MATLAB menyenangkan karena membuat pekerjaan program linier menjadi lebih mudah, lebih cepat menentukan hasilnya, meminimalisir kesalahan, serta pembelajaran lebih menarik. Selain itu mahasiswa lebih memahami materi program linear dengan adanya penerapan software MATLAB. Mahasiswa dapat menggunakan software MATLAB untuk menyelesaikan masalah program linear dikarenakan angkah-langkah pengerjaannya yang mudah dipahami.

\section{SIMPULAN}

Penelitian ini memberikan simpulan bahwa terdapat pengaruh penerapan software MATLAB terhadap kemampuan menyelesaikan masalah program linier mahasiswa pada program studi pendidikan matematika Universitas PGRI Adi Buana Surabaya yang ditunjukkan melalui nilai U pada uji Mann Whitney sebesar 308.500 dengan nilai sig. ( $p$-value) sebesar 0,000 < 0,05 . Kondisi ini mengartikan bahwa terdapat perbedaan yang siginifikan antara rata-rata kemampuan mahasiswa kelas 2016A dan kelas 2016B dalam menyelesaikan masalah program linier.

Penerapan software MATLAB dalam pembelajaran program linier di Pendidikan Matematika Universitas PGRI Adi Buana Surabaya mendapat tanggapan positif dari mahasiswa. Mahasiswa merasa senang dengan adanya penerapan software MATLAB pada materi program linier, mahasiswa memahami dan dapat menggunakan software MATLAB untuk menyelesaikan masalah program linear, serta mahasiswa tidak mengalami kesulitan dalam menyelesaikan masalah program linear dengan menggunakan software MATLAB.

\section{UCAPAN TERIMA KASIH}

Peneliti mengucapkan terimakasih kepada Kementrian Riset dan Teknologi Pendidikan Tinggi yang telah mendanai penelitian ini, selain itu peneliti juga mengucapkan terimakasih kepada mahasiswa program studi pendidikan matematika Universitas PGRI Adi Buana Surabaya yang telah berkontribusi pada penelitian ini.

\section{DAFTAR PUSTAKA}

Astutik, E.P., Fitriatien, S.R. 2016. Metode Statistika. Surabaya: Adi Buana University Press.

Indriani, Suyitno, Mashuri. 2013. "Analisis Metode Karmarkar untuk Menyelesaikan Masalah Program Linier". Jurnal MIPA. Vol. 36 (1), pp:98-106.

Novita, Dian. 2016. "Pengaruh Penggunaan Multimedia Interkatif terhadap Kemampuan Pemahaman Konsep Matematis Siswa". Fibonacci: Jurnal Pendidikan Matematika dan Matematika. Vol. 2 (2), pp: 8-18.

Rosiyanti, Hastri. 2016. "Penggunaan Software LINDO dengan Metode Pembelajaran Penemuan Terbimbing untuk Meningkatkan Motivasi Belajara Mahasiswa Matematika Angkatan 2013 pada Mata Kuliah Program Linier". Fibonacci: Jurnal Pendidikan Matematika dan Matematika. Vol. 2 (2), pp: 19-27.

Sobiruddin, D. 2015. "Penerapan Software Matlab terhadap kemampuan Menyelesaikan Masalah Numerik Mahasiswa Jurusan Pendidikan 
FIBONACCI : Jurnal Pendidikan Matematika dan Matematika

Volume 5 No. 2 Bulan Desember Tahun 2019

Matematika". Jurnal Pendidikan Matematika PARADIKMA. Vol. 8 (1), pp: 24-32.

Sugiyono. 2013. Metode Penelitian Pendidikan. Bandung: Alfabeta.
Sugiyono. 2017. Metode Penelitian Pendidikan Pendekatan Kuantitatif, Kualitatif, dan $R \& D$. Bandung: Alfabeta.

Zulfikarijah, F. 2004. Operation Research. Malang: Bayumedia Publishing. 